\title{
Impact of second line limiting amino acids' deficiency in broilers fed low protein diets with rapeseed meal and de-oiled rice bran
}

\author{
C. Basavanta Kumar $^{1}$, R. G. Gloridoss ${ }^{1}$, K. Chandrapal Singh ${ }^{2}$, T. M. Prabhu', Siddaramanna ${ }^{3}$, B. N. Suresh ${ }^{4}$ \\ and G. A. Manegar
}

1. Department of Animal Nutrition, Veterinary College, Hebbal, Bangalore, India; 2. Division of Animal Sciences, Karnataka Veterinary, Animal and Fisheries Sciences University, Hebbal, Bangalore, India; 3. Senior Technical Officer, Southern Research Station, National Dairy Research Institute, Bangalore, India; 4. Department of ILFC, Veterinary College, Hassan, India; 5. Department of Animal Science, Krishi Vignyana Kendra, Bangalore Rural Dist, India. Corresponding author: C. Basavanta Kumar, email: basavantac216@gmail.com,

RGG: gideongloridoss@gmail.com, KCS: profchandrapal@gmail.com, TMP: prabhutmann@gmail.com, S: sidaramanna@gmail.com, BNS: suresh658@rediffmail.com, GAM: dranandamanegar@gmail.com Received: 24-11-2014, Revised: 05-02-2015, Accepted: 13-02-2015, Published online: 18-03-2015

doi: 10.14202/vetworld.2015.350-357. How to cite this article: Basavanta Kumar C, Gloridoss RG, Singh KC, Prabhu TM, Siddaramanna, Suresh BN, Manegar GA (2015) Impact of second line limiting amino acids' deficiency in broilers fed low protein diets with rapeseed meal and de-oiled rice bran, Veterinary World 8(3):350-357.

\begin{abstract}
Aim: To study the impact of deficiency of second line limiting amino acids (SLAA; valine, isoleucine and tryptophan) on the production performance and carcass characteristics of commercial broilers.

Materials and Methods: A control $\left(\mathrm{T}_{1}\right)$ corn-soy diet was formulated to contain all essential AA on standardized ileal digestible basis; While in $\mathrm{T}_{2}$-a 'moderate SLAA deficit' diet was formulated by replacement of soybean meal with $6 \%$ rapeseed meal and $\mathrm{T}_{3}$-a 'high SLAA deficit' diet was formulated by replacement of soybean meal with $6 \%$ de-oiled rice bran. Each of these treatments was allotted to six replicates of ten chicks each. During the 42 days experimental period, growth performance, carcass parameters and intake of metabolizable energy (ME), crude protein (CP) and AA were studied.

Results: The cumulative body weight gain, feed conversion ratio, carcass cut weights and yields of carcass, breast and thighs were decreased $(p<0.05)$ in $T_{3}$ compared to $T_{1}$. The absolute intake of ME, lysine, methionine + cysteine and threonine were not affected while intake of CP and all SLAA were reduced in SLAA deficit diets. The relative intake of ME, lysine, methionine + cysteine, threonine and SLAA reduced in $\mathrm{T}_{3}$ in comparison to $\mathrm{T}_{1}$. The relative weights of internal organs were not affected by treatments while the abdominal fat percentage was increased linearly to the magnitude of SLAA deficiency.
\end{abstract}

Conclusion: The deficiency of SLAA decreased performance, carcass yields and impaired utilization of ME, CP and AA linearly to the magnitude of the deficiency.

Keywords: isoleucine, tryptophan and broilers, valine.

\section{Introduction}

Protein is un-debatably an important nutrient for poultry and should be an integral part of the diet. Protein rich ingredients accounts for $30-40 \%$ of the ration yet play an imperative role in determining the feed cost. It is universally accepted that, birds as such do not have a need for crude protein (CP) rather there is a need for amino acids (AA). In commercial poultry feed formulations, the first line of limiting AA are supplemented extensively as DL-methionine, L-lysine and L-threonine to rationalize the AA levels and to economize feed cost on corn soy diets. Lowering the dietary CP levels and use of synthetic AA perhaps reduce the cost of diet and the environmental pollution of nitrogen [1]. Hence, reduction of protein through inclusion of locally available feed ingredients such as rape seed meal (RSM) and de oiled rice bran (DORB) can be thought of as an alternative solution.

In previous studies, the RSM was used up to a level of $6-10 \%$ of the ration [2-4]. Very similarly,

Copyright: The authors. This article is an open access article licensed under the terms of the Creative Commons Attributin License (http:// creative commons.org/licenses/by/2.0) which permits unrestricted use, distribution and reproduction in any medium, provided the work is properly cited. although the DORB was included up to $20 \%$ in broiler rations $[5,6]$, yet other reports $[7,8]$ indicate deleterious effects of DORB on broiler performance. However, it is noteworthy to state that, none of the studies conducted with inclusion of either RSM or DORB addressed the issue of protein reduction, and moreover, the soybean meal content was adjusted to make the diets iso-nitrogenous. Furthermore, the level of L-lysine maintained in such studies was far below the level recommended for present day commercial broilers, which allowed safe use of these resources, without causing deficiency of third and subsequent limiting AA. Formulation of diets based on standardized ileal digestible AA was suggested as a means for better utilization of alternative feed ingredients [9]. However, in RSM and DORB based low CP diets formulated to meet the recommended ideal standardized ileal digestible (SID) AA ratio profile [10], valine, isoleucine and occasionally tryptophan were found to be second line limiting AA notwithstanding the supplementation of L-lysine, DL-methionine and L-threonine.

Since, CP reduction was a theme of this study, RSM and DORB were incorporated to reduce CP by 
replacing soybean meal on $\mathrm{W} / \mathrm{W}$ basis $(6 \%)$, and the resultant impact and gravity of second line limiting AA (SLAA) (valine, isoleucine and tryptophan) deficiency on the broiler performance, carcass characteristics and intake of nutrients were assessed in this study.

\section{Materials and Methods}

\section{Ethical approval}

Prior approval of Institutional Animal Ethics Committee was obtained for use of chicks and experimental procedures adopted in this study.

\section{Ingredients and AA analysis}

Sufficient quantities of required feed ingredients were procured and analyzed for proximate principles [11]. Each ingredient was analyzed for AA composition at Evonik Laboratory. The feed formulation was done using the laboratory estimated $\mathrm{CP}$ and prorata AA composition of ingredients [12]. The AA profile of the experimental diets was arrived at based on the analyzed AA profile of each raw material.

\section{Experimental design and diets}

A control $\left(\mathrm{T}_{1}\right)$ broiler diet formulated to meet recommended ideal SID AA ratio [10] in such a way to meet the requirement of fourth limiting AA (valine/ isoleucine depending on the feeding phase) under pre-starter (0-14 days), starter (15-28 days) and finisher (29-42 days) phases (Table-1). In the test diet $\mathrm{T}_{2}$ (moderate SLAA deficiency), soybean meal was replaced on W/W basis with $6 \%$ RSM and the levels of lysine, methionine + cysteine and threonine were maintained as in $\mathrm{T}_{1}$ with supplemental feed grade AA. Similarly, in $\mathrm{T}_{3}$ (high SLAA deficiency) soybean meal was replaced on $\mathrm{W} / \mathrm{W}$ basis with $6 \%$ DORB and here also the levels of lysine, methionine + cysteine and threonine were maintained on par with control through supplementation. Diets were formulated to contain the same energy, calcium, and available phosphorus while the CP was allowed to dilute. The acidbase imbalance in low protein diets was corrected on par to control. The nutrient and AA composition of experimental diets is presented in Table-2. The magnitude of SLAA deficiency created with replacement of soybean meal by RSM and DORB in test diets is presented in Table-3.

\section{Experimental birds}

A total of 180 day-old straight run commercial broiler chicks were weighed, wing banded and divided into eighteen homogenous groups with ten chicks in each pen. The three experimental diets were randomly allocated to six pens each and each pen was considered as one experimental unit. All the chicks were reared in deep litter system in conventional open ventilated sheds with standard vaccination program and uniform managemental practices throughout the experiment.

\section{Parameters studied}

Growth performance parameters: Feed intake and body weight of the individual birds in each replicate were recorded at weekly intervals. The mortality of the bird was recorded as and when occurred. The mortality corrected feed conversion ratio (FCR) was calculated as unit feed intake to the unit body weight gain (BWG).

Dressing percentage and organometry: Two birds from each replicate were randomly selected at the end of the trial ( $42^{\text {nd }}$ day), starved overnight with the provision for ad lib water and sacrificed by cervical dislocation. The dressing percentage was calculated as the percent of the carcass weight to the body weight after removing the feathers, neck, legs and internal viscera.

Table-1: Ingredient composition of the experimental diets.

\begin{tabular}{|c|c|c|c|c|c|c|c|c|c|}
\hline \multirow[t]{2}{*}{ Ingredient ( $\mathrm{Kg} /$ ton) } & \multicolumn{3}{|c|}{ Pre-starter diet } & \multicolumn{3}{|c|}{ Starter diet } & \multicolumn{3}{|c|}{ Finisher diet } \\
\hline & $\mathbf{T}_{1}$ & $\mathbf{T}_{2}$ & $\mathbf{T}_{3}$ & $\mathbf{T}_{1}$ & $\mathbf{T}_{\mathbf{2}}$ & $\mathbf{T}_{\mathbf{3}}$ & $\mathbf{T}_{1}$ & $\mathbf{T}_{\mathbf{2}}$ & $\mathbf{T}_{3}$ \\
\hline Maize & 484.5 & 475.5 & 473.0 & 537.0 & 527.5 & 524.5 & 597.0 & 587.5 & 585.0 \\
\hline Meat and bone meal & - & - & - & 40.0 & 40.0 & 40.0 & 50.0 & 50.0 & 50.0 \\
\hline Rapeseed meal & - & 60.0 & - & - & 60.0 & - & - & 60.0 & - \\
\hline DORB & - & - & 60.0 & - & - & 60.0 & - & - & 60.0 \\
\hline Soybean meal & 421 & 361 & 361 & 350.7 & 290.7 & 290.7 & 282.1 & 222.1 & 221.1 \\
\hline Dicalcium phosphate & 20.0 & 20.0 & 20.0 & 7.5 & 7.5 & 7.5 & 4.5 & 4.5 & 4.5 \\
\hline Calcite powder & 12.5 & 12.2 & 12.9 & 5.3 & 5.0 & 5.7 & 4.1 & 4.0 & 4.7 \\
\hline Salt & 4.0 & 4.0 & 4.0 & 4.0 & 4.0 & 4.0 & 4.0 & 4.0 & 4.0 \\
\hline Soda bicarbonate & 0.5 & 0.5 & 0.5 & 0.5 & 0.5 & 0.5 & 0.5 & 0.5 & 0.5 \\
\hline Trace mineral premix ${ }^{1}$ & 1.0 & 1.0 & 1.0 & 1.0 & 1.0 & 1.0 & 1.0 & 1.0 & 1.0 \\
\hline Vegetable oil & 46.9 & 53.7 & 53.4 & 44.3 & 51.3 & 51.0 & 47.2 & 54.2 & 53.9 \\
\hline L-lysine monohydrochloride & 0.78 & 1.66 & 2.79 & 0.98 & 1.86 & 2.98 & 1.02 & 1.90 & 3.03 \\
\hline DL-methionine & 3.27 & 3.12 & 4.03 & 3.19 & 3.05 & 3.95 & 2.79 & 2.64 & 3.55 \\
\hline L-threonine & 0.36 & 0.62 & 1.30 & 0.49 & 0.75 & 1.43 & 0.46 & 0.72 & 1.41 \\
\hline Potassium carbonate & - & 1.05 & 0.73 & - & 1.08 & 0.76 & - & 1.07 & 0.74 \\
\hline Additives $^{2}$ & 6.00 & 6.00 & 6.00 & 6.00 & 6.00 & 6.00 & 6.00 & 6.00 & 6.00 \\
\hline Total & 1000.8 & 1000.4 & 1000.6 & 1000.7 & 1000.4 & 1000.3 & 1000.5 & 1000.6 & 1000.1 \\
\hline
\end{tabular}

${ }^{1}$ Contained Fe-90000 ppm, I-2000 ppm, Cu-15000 ppm, Mn-90000 ppm, Zn-80000 ppm, Se-300 ppm, ${ }^{2}$ Contained vitamin A-10 mIU, D3-2.0 mIU, E-30.0 g, C-50 g, B-2.0 g, B $-10.0 \mathrm{~g}, \mathrm{~B}_{6}-3.0 \mathrm{~g}, \mathrm{~B}_{12}-0.015$, Niacin-30.0 g, calcium-d-pantothenate $15.0 \mathrm{~g}$, biotin- $0.10 \mathrm{~g}$, folic acid- $2.0 \mathrm{~g}$ and vitamin-K-4.0 g; herbal liver stimulant-1700 g; semduramicin-30.0 g; tetracyclin-30.00 g; a commercial toxin binder-2000 g, DORB=De oiled rice bran 
Table-2: Nutrient and amino acid composition of the experimental diets under different phases.

\begin{tabular}{|c|c|c|c|c|c|c|c|c|c|}
\hline \multirow[t]{2}{*}{ Ingredient (Kg/ton) } & \multicolumn{3}{|c|}{ Pre-starter diet } & \multicolumn{3}{|c|}{ Starter diet } & \multicolumn{3}{|c|}{ Finisher diet } \\
\hline & $\mathbf{T}_{1}$ & $\mathbf{T}_{2}$ & $\mathbf{T}_{3}$ & $\mathbf{T}_{1}$ & $\mathbf{T}_{2}$ & $\mathbf{T}_{3}$ & $\mathbf{T}_{1}$ & $\mathbf{T}_{2}$ & $\mathbf{T}_{3}$ \\
\hline $\mathrm{CP}$ (analyzed, \%) & 23.25 & 22.83 & 21.73 & 22.44 & 22.02 & 20.93 & 20.33 & 19.91 & 18.82 \\
\hline ME (Kcal/kg; calculated) & 3000 & 3000 & 3000 & 3100 & 3100 & 3100 & 3200 & 3200 & 3200 \\
\hline Calcium \% & 1.01 & 1.01 & 1.01 & 0.91 & 0.91 & 0.91 & 0.89 & 0.90 & 0.89 \\
\hline$P_{a v} \%$ & 0.47 & 0.47 & 0.48 & 0.45 & 0.45 & 0.46 & 0.44 & 0.45 & 0.45 \\
\hline \multicolumn{10}{|c|}{$\begin{array}{l}\text { Amino acid composition (as SID } \\
\text { calculated from analyzed value*) (\%) }\end{array}$} \\
\hline Lysine & 1.204 & 1.205 & 1.205 & 1.120 & 1.120 & 1.120 & 0.983 & 0.983 & 0.983 \\
\hline Methionine+cystine & 0.882 & 0.883 & 0.882 & 0.840 & 0.840 & 0.840 & 0.757 & 0.757 & 0.757 \\
\hline Threonine & 0.772 & 0.773 & 0.773 & 0.728 & 0.728 & 0.728 & 0.649 & 0.649 & 0.649 \\
\hline Valine & 0.953 & 0.924 & 0.838 & 0.896 & 0.851 & 0.779 & 0.803 & 0.763 & 0.688 \\
\hline Isoleucine & 0.885 & 0.843 & 0.775 & 0.806 & 0.751 & 0.696 & 0.708 & 0.666 & 0.598 \\
\hline Tryptophan & 0.240 & 0.233 & 0.209 & 0.211 & 0.205 & 0.180 & 0.180 & 0.173 & 0.149 \\
\hline
\end{tabular}

*SID coefficients were taken from (3), SID=Standardized ileal digestible, CP=Crude protein, ME=Metabolizable energy

Table-3: The relative percentage of SID valine, isoleucine and tryptophan composition* as affected by inclusion of RSM and DORB.

\begin{tabular}{|c|c|c|c|c|c|c|c|c|c|}
\hline \multirow{2}{*}{$\begin{array}{l}\text { Amino } \\
\text { acid }\end{array}$} & \multicolumn{3}{|c|}{ Pre starter } & \multicolumn{3}{|c|}{ Starter } & \multicolumn{3}{|c|}{ Finisher } \\
\hline & $T_{1}$ & $T_{2}$ & $\mathbf{T}_{3}$ & $T_{1}$ & $T_{2}$ & $\mathbf{T}_{3}$ & $\mathbf{T}_{1}$ & $T_{2}$ & $\mathbf{T}_{3}$ \\
\hline & & & & & & & & & \\
\hline & & & & & & & & & \\
\hline & & & 108 & & & & & & \\
\hline \multicolumn{10}{|c|}{$\begin{array}{l}\text { : Control; } T_{2}: \text { Moderate SLAA deficit diet; } T_{3}: \text { High } \\
\text { LAA deficit diet, *as compared to the ideal SID AA ratio } \\
\text { ecommended by }(3), A A=A m i n o \text { acid, SLAA }=\text { Second line } \\
\text { miting amino acids, SID=Standardized ileal digestible, } \\
\text { ORB = De oiled rice bran, RSM=Rape seed meal }\end{array}$} \\
\hline
\end{tabular}

Weight of different cuts viz., breast, thigh, drumstick and wing of the carcass was taken, and each part was expressed as a percent of pre-slaughter live weight $(\mathrm{g} / 100 \mathrm{~g})$. From each sacrificed bird, the weight of the giblet organs viz., heart (without pericardium), liver (without gall bladder) and gizzard (without inner layer) and additionally weight of abdominal fat was recorded and expressed as the per cent of pre-slaughter live weight $(\mathrm{g} / 100 \mathrm{~g})$.

Intake of ME, CP and AA: Based on the feed intake, intake of ME calculated based on the reported value while the $\mathrm{CP}$ and $\mathrm{AA}$ intakes were calculated based on the analyzed CP and AA composition.

\section{Statistical analysis}

The experimental data were statistically analyzed by one-way ANOVA using means of six variants for each treatment. Tukey's test with $\mathrm{p}<0.05$ was used for mean separation wherever treatment effect was significant $(p<0.05)$. Statistical analysis of data was performed using GraphPad Prism [13].

\section{Results}

Inclusion of $6 \%$ RSM at pre-starter phase resulted in marginal deficiency (Table-3) of valine alone $(3 \%)$ while at starter and finisher phase, both valine $(5 \%$ and $2 \%)$ and isoleucine (4\% and $6 \%$ ) were found to be deficit. The DORB inclusion at pre-starter and starter phase resulted in both valine $(12 \%$ and $13 \%)$ and isoleucine $(5 \%$ and $11 \%$ ) deficiency while at finisher phase, in addition to deficiency of valine $(13 \%)$ and isoleucine $(15 \%)$, deficiency of tryptophan (11\%) was also evident. The results imply that deficiency of valine was much larger than that of isoleucine and tryptophan in that order during pre-starter and starter phase while it was almost similar during finisher phase.

The BWG (Table-4) of birds was found to be significantly affected by treatments at all stages of life. During pre-starter phase, BWG in $\mathrm{T}_{3}$ was significantly $(p<0.05)$ reduced by $14.21 \%$ compared to that of $\mathrm{T}_{1}$, while $\mathrm{T}_{2}$ remained non-significant from both $\mathrm{T}_{3}$ and $T_{1}$. However, the trend in the starter phase was quite different with significant $(\mathrm{p}<0.05)$ reduction of BWG in both $\mathrm{T}_{2}$ and $\mathrm{T}_{3}$ by 10.43 and $10.77 \%$ respectively from $T_{1}$. However, in the finisher phase, only high SLAA deficiency resulted in significant $(p<0.05)$ BWG reduction, but not the moderate deficiency group. On overall cumulative basis, the BWG in $\mathrm{T}_{2}(4.98 \%)$ and $\mathrm{T}_{3}(7.48 \%)$ were significantly $(\mathrm{p}<0.05)$ inferior to that of control and the response was found to be significantly $(\mathrm{p}<0.001)$ linear to the magnitude of SLAA deficiency. The feed intake (FI) in $\mathrm{T}_{3}$ during pre-starter phase was significantly $(\mathrm{p}<0.05)$ reduced $(4.48 \%)$ in comparison to that of control and the FI in $\mathrm{T}_{2}$ was statistically similar ( $\mathrm{p} \geq 0.05$ ) to those of $\mathrm{T}_{1}$ and $\mathrm{T}_{3}^{2}$ groups whereas, in contrast, during starter phase, $\mathrm{T}_{2}$ was significantly $(\mathrm{p}<0.05)$ inferior to $\mathrm{T}_{1}$ and was non-significant with the $T_{3}$ which stood in middle. However in contrary, during the finisher phase and on the cumulative basis there was a non-significant effect of treatments on the FI. The FCR (Table-4) was significantly $(p<0.001)$ altered due to SLAA deficiency throughout the phases and cumulatively as well. FCR was significantly $(p<0.05)$ different in each treatment during pre-starter and finisher phases. On the other hand, at starter phase, FCR in $\mathrm{T}_{2}$ and $\mathrm{T}_{3}$ was significantly $(\mathrm{p}<0.05)$ deprived than control despite of being non-significant from each other. On cumulative basis in $\mathrm{T}_{2}$ and $\mathrm{T}_{3}$, a significantly $(\mathrm{p}<0.05)$ poor FCR of magnitude 0.039 and 0.061 units was evident in contrast to control with a clear-cut linear effect of SLAA deficiency $(\mathrm{p}<0.001)$. The mortality rate was 


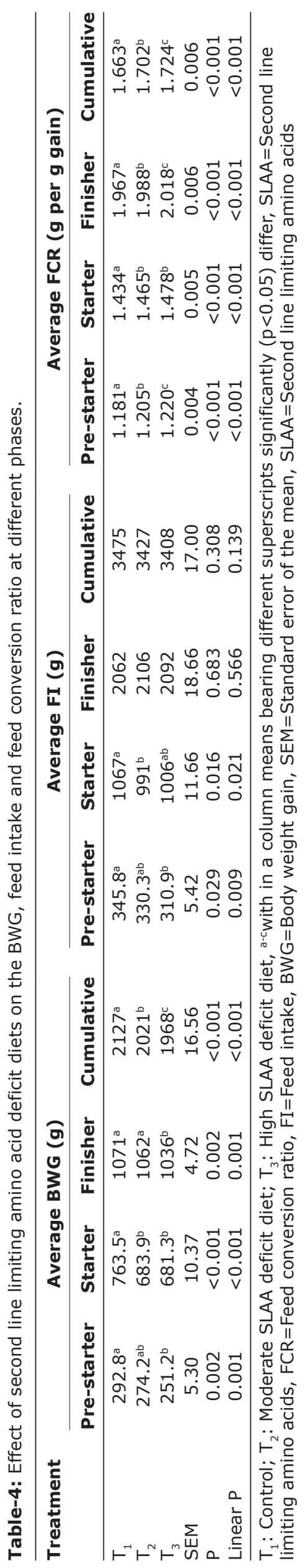

numerically high in $\mathrm{T}_{3}(5.00 \%)$ and $\mathrm{T}_{2}(3.33 \%)$ in comparison to $\mathrm{T}_{1}(2.00 \%)$ although it was statistically non-significant.

The fresh carcass weight (Table-5) was significantly $(\mathrm{p}<0.05)$ inferior to $\mathrm{T}_{1}$ in both treatments with SLAA deficiency. The weight of the breast, thigh, drumstick and wing were significantly $(\mathrm{p}<0.05)$ different in $\mathrm{T}_{3}$ vis-a-vis $\mathrm{T}_{1}$ and the corresponding weights in $\mathrm{T}_{2}$ were non-significant from both $\mathrm{T}_{1}$ and $\mathrm{T}_{3}$. The carcass yield, breast yield and thigh yield as percent of live weight were significantly $(p<0.05)$ decreased due to SLAA deficiency and in contrary the drumstick and wing yield remained non-significant. The impact of SLAA deficiency was not evident on the relative weights of internal organs viz., liver, gizzard and heart (Figure-1), though the relative weight of abdominal fat was significantly $(p<0.05)$ elevated with SLAA deficiency.

The impact of SLAA deficiency on the intake of ME, lysine, sulfur AA (methionine + cystine) and threonine (Table-6) per bird was not evident, while the corresponding measure for CP and SLAA was decreased in a linear $(p<0.001)$ fashion as the level of SLAA deficiency magnified. The absolute intake of valine, isoleucine and tryptophan was significantly $(\mathrm{p}<0.05)$ decreased in $\mathrm{T}_{2}$ and $\mathrm{T}_{3}$ in comparison to $\mathrm{T}_{1}$ and further, difference between both $T_{2}$ and $T_{3}$ was quite significantly $(p<0.05)$ noticeable. The decreasing trend in the intake of SLAA was significantly $(p<0.001)$ linear to the extent of the insufficiency. When the intake of these nutrients were expressed to unit weight gain, it was interesting to note that, the ME intake increased linearly to the enormity of SLAA insufficiency. On the other hand, the CP intake per Kg of BWG was incoherent with SLAA deficiency. The intake of lysine, methionine + cystine and threonine per unit of BWG was found to be significantly $(p<0.003)$ amplified to the magnitude of SLAA deficiency. Intake of lysine, methionine + cysteine and threonine per kg BWG in $\mathrm{T}_{3}$ was significantly $(\mathrm{p}<0.05)$ elevated compared to $\mathrm{T}_{1}$, although the difference was non-significant from $\mathrm{T}_{2}$. The valine $(\mathrm{g} / \mathrm{kg} \mathrm{BWG})$ intake in $\mathrm{T}_{2}$ was non-significant with control whereas in $\mathrm{T}_{3}$ it was significantly lower than $\mathrm{T}_{1}$. Considering intake of valine and

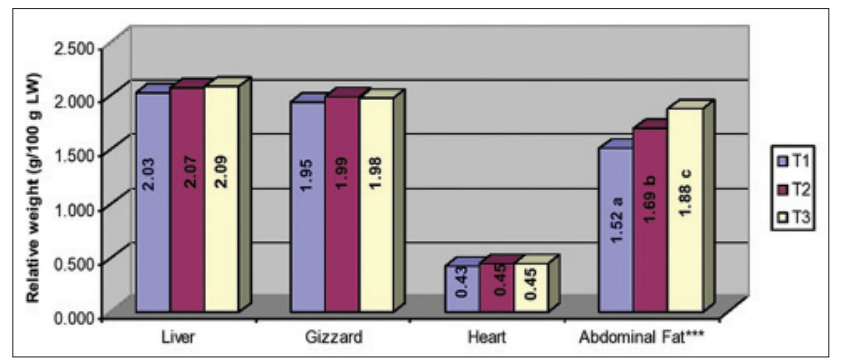

Figure-1: Effect of second line limiting amino acid deficit diets on relative weights of liver, gizzard, heart and abdominal fat of broilers, $\mathrm{T}_{1}$ - Control; $\mathrm{T}_{2}$ - Moderate SLAA deficit diet; $T_{3}$ - High SLAA deficit diet; * Methionine + Cysteine, ${ }^{a-c}$ Within a column means bearing different superscripts significantly $(p<0.05)$ differ 
Available at www.veterinaryworld.org/Vol.8/March-2015/16.pdf

Table-5: Effect of second line limiting amino acid deficit diets on carcass characteristics of broilers at the end of 42 days.

\begin{tabular}{|c|c|c|c|c|c|c|c|c|c|c|}
\hline \multirow[t]{2}{*}{ Treatment } & \multicolumn{5}{|c|}{ Carcass cuts (weight in g) } & \multicolumn{5}{|c|}{ Carcass yield (percent of live weight) } \\
\hline & $\begin{array}{c}\text { Fresh } \\
\text { Carcass }\end{array}$ & $\begin{array}{c}\text { Breast } \\
\text { Weight }\end{array}$ & $\begin{array}{c}\text { Thigh } \\
\text { Weight }\end{array}$ & Drumstick & Wing & $\begin{array}{c}\text { Fresh } \\
\text { Carcass }\end{array}$ & $\begin{array}{l}\text { Breast } \\
\text { Yield }\end{array}$ & $\begin{array}{l}\text { Thigh } \\
\text { Yield }\end{array}$ & $\begin{array}{c}\text { Drumstick } \\
\text { Yield }\end{array}$ & $\begin{array}{l}\text { Wing } \\
\text { Yield }\end{array}$ \\
\hline T1 & $1593^{a}$ & $482.0^{a}$ & $293.9^{a}$ & $222.0^{a}$ & $180.5^{\mathrm{a}}$ & $74.66^{\mathrm{a}}$ & $22.58^{a}$ & $13.76^{a}$ & 10.39 & 8.45 \\
\hline T2 & $1479^{b}$ & $445.3^{\mathrm{ab}}$ & $265.9^{a b}$ & $204.8^{\mathrm{ab}}$ & $165.7^{\mathrm{ab}}$ & $73.10^{\mathrm{b}}$ & $22.00^{\mathrm{ab}}$ & $13.13^{\mathrm{ab}}$ & 10.11 & 8.18 \\
\hline T3 & $1443^{b}$ & $424.6^{b}$ & $247.8^{b}$ & $192.6^{b}$ & $154.0^{\mathrm{b}}$ & $72.31^{\mathrm{b}}$ & $21.26^{b}$ & $12.40^{\mathrm{b}}$ & 9.63 & 7.70 \\
\hline SEM & 18.58 & 7.32 & 5.40 & 4.43 & 4.10 & 0.239 & 0.194 & 0.172 & 0.153 & 0.152 \\
\hline$P$ & 0.003 & 0.006 & 0.002 & 0.030 & 0.037 & $<0.001$ & 0.023 & 0.005 & 0.143 & 0.150 \\
\hline Linear $\mathrm{P}$ & 0.001 & 0.001 & 0.001 & 0.009 & 0.011 & $<0.001$ & 0.007 & 0.001 & 0.055 & 0.059 \\
\hline
\end{tabular}

$\mathrm{T}_{1}$ : Control; $\mathrm{T}_{2}$ : Moderate SLAA deficit diet; $\mathrm{T}_{3}$ : High SLAA deficit diet, ${ }^{\mathrm{a}-\mathrm{c} W i t h i n}$ a column means bearing different superscripts significantly $(p<0.05)$ differ, SEM=Standard error mean, SLAA=Second line limiting amino acids

Table-6: Impact of second line limiting amino acid deficiency on cumulative absolute and relative intake of $\mathrm{ME}, \mathrm{CP}$ and Amino Acids.

\begin{tabular}{|c|c|c|c|c|c|c|c|c|}
\hline & $\begin{array}{c}\text { ME } \\
\text { (M cal) }\end{array}$ & $\begin{array}{l}\text { CP } \\
(\mathrm{g})\end{array}$ & $\begin{array}{l}\text { Lysine } \\
\text { (g) }\end{array}$ & $\begin{array}{c}\mathrm{M}+\mathrm{C} * \\
(\mathrm{~g})\end{array}$ & $\begin{array}{l}\text { Threonine } \\
\text { (g) }\end{array}$ & $\begin{array}{c}\text { Valine } \\
\text { (g) }\end{array}$ & $\begin{array}{c}\text { Isoleucine } \\
\text { (g) }\end{array}$ & $\begin{array}{l}\text { Tryptophan } \\
\text { (g) }\end{array}$ \\
\hline \multicolumn{9}{|c|}{ Intake per bird } \\
\hline $\mathrm{T}_{1}$ & 10.95 & $740^{a}$ & 36.32 & 27.68 & 23.82 & $29.42^{\mathrm{a}}$ & $26.25^{\mathrm{a}}$ & $6.79^{a}$ \\
\hline $\mathrm{T}_{2}^{1}$ & 10.80 & $713^{b}$ & 35.74 & 27.24 & 23.47 & $27.55^{b}$ & $24.25^{b}$ & $6.43^{b}$ \\
\hline $\mathrm{T}_{3}^{2}$ & 10.74 & $672^{c}$ & 35.53 & 27.08 & 23.33 & $24.82^{c}$ & $21.92^{c}$ & $5.58^{c}$ \\
\hline SEM & 0.054 & 7.447 & 0.175 & 0.134 & 0.114 & 0.476 & 0.439 & 0.127 \\
\hline $\mathrm{P}$ & 0.349 & $<0.001$ & 0.203 & 0.219 & 0.237 & $<0.001$ & $<0.001$ & $<0.001$ \\
\hline Linear $\mathrm{P}$ & 0.162 & $<0.001$ & 0.086 & 0.094 & 0.102 & $<0.001$ & $<0.001$ & $<0.001$ \\
\hline \multicolumn{9}{|c|}{ Intake per kg live weight gain } \\
\hline $\mathrm{T}_{1}$ & $5.15^{\mathrm{a}}$ & 348 & $17.08^{\mathrm{a}}$ & $13.01^{\mathrm{a}}$ & $11.20^{\mathrm{a}}$ & $13.83^{a}$ & $12.34^{\mathrm{a}}$ & $3.19^{a}$ \\
\hline $\mathrm{T}_{2}$ & $5.35^{\mathrm{ab}}$ & 353 & $17.69^{\mathrm{ab}}$ & $13.48^{\mathrm{ab}}$ & $11.61^{\mathrm{ab}}$ & $13.64^{a}$ & $12.00^{\mathrm{a}}$ & $3.18^{\mathrm{a}}$ \\
\hline $\mathrm{T}_{3}^{2}$ & $5.46^{b}$ & 341 & $18.06^{b}$ & $13.77^{b}$ & $11.86^{b}$ & $12.61^{\mathrm{b}}$ & $11.14^{\mathrm{b}}$ & $2.83^{b}$ \\
\hline SEM & 0.04 & 2.24 & 0.14 & 0.11 & 0.090 & 0.157 & 0.140 & 0.044 \\
\hline$P$ & 0.009 & 0.103 & 0.008 & 0.008 & 0.007 & $<0.001$ & $<0.001$ & $<0.001$ \\
\hline Linear $\mathrm{P}$ & 0.003 & 0.233 & 0.002 & 0.003 & 0.002 & $<0.001$ & $<0.001$ & $<0.001$ \\
\hline
\end{tabular}

$\mathrm{T}_{1}$ - Control; $\mathrm{T}_{2}$ - Moderate SLAA deficit diet; $\mathrm{T}_{3}$ : High SLAA deficit diet; *Methionine+Cysteine, ${ }^{\mathrm{a}-\mathrm{c} \text { Within a column means }}$ bearing different superscripts significantly $(p<0.05)$, differ, SLAA=Second line limiting amino acids

isoleucine, it was interesting to note that, intake per kg BWG was statistically non-significant in $\mathrm{T}_{2}$ visa-vis $\mathrm{T}_{1}$ and the difference was significant only in $\mathrm{T}_{3}$ with high degree of SLAA deficiency. The trend of decreasing SLAA intake to the magnitude of SLAA deficiency was highly significantly $(p<0.001)$ linear.

\section{Discussion}

The BWG of birds was significantly reduced by SLAA deficiency at all stages of life, which is a clear reflection of impact of treatments on the input of critical nutrients channeled through feed intake and it was found that the bids eat to satisfy the need for a limiting nutrient, and in this attempt the birds might have failed as a result of bulkiness of the feed or the inability of birds to lose sufficient heat to remain in thermal balance, which follows the principles of the Theory of food intake and growth proposed by Emmans $[14,15]$. The deficiency of SLAA resulted in significantly lower absolute intake of valine and isoleucine (in $\mathrm{T}_{2}$ ) and additionally tryptophan (in $\mathrm{T}_{3}$; Table-6) which perhaps impeded protein accretion and hence the growth performance of broilers, since AA have been revealed to influence the myogenic gene expression in broilers [16]. The growth retardation as a consequence to SLAA deficiency is well noticed in previous studies with deficiencies of valine alone in young broilers [17,18], valine and isoleucine [1,19], isoleucine, tryptophan and arginine [20], isoleucine alone [21,22] and arginine, valine, isoleucine and tryptophan [23]. With marginal SLAA deficiency in the finisher phase, birds could compensate to the SLAA intake at this time period (data not shown) and as a consequence, birds could grow on par with control which is suggestive of the compensatory growth during this period due to moderate but not for high SLAA deficiency. The feed intake which was reduced due to SLAA deficiency in the initial pre-starter and starter phases was found to be compensated in the finisher phase suggestive of the adoptive nature of birds to consume more feed owing to relatively well developed intestinal segments at this stage. The non-alteration of cumulative feed intake is largely due to an elevated fatness indicated in SLAA deficit treatments during finisher phase, for obvious reasons discussed above. The reduction of feed intake consequent to the high SLAA deficiency is supported by the studies of [17] with valine, [24] with isoleucine, glycine, glutamic acid and that of [22] with isoleucine deficiencies. In addition, non-alteration of feed intake due to marginal deficiency of valine was reported in finisher broilers [25] is indicative of the adoptive behavior of birds to marginal deficiency of SLAA. The poor FCR of magnitude $0.039\left(\mathrm{~T}_{2}\right)$ and $0.061\left(\mathrm{~T}_{3}\right)$ units 
observed in this study is supportive to the earlier findings with valine $(17 ; 25)$, with isoleucine, glycine and glutamic acid [24], with isoleucine, tryptophan and arginine [20] and with valine and isoleucine [26,27] deficiencies.

The linear decrease in fresh carcass weight to the magnitude of SLAA deficiency perhaps reflects the response observed for BWG for the reasons discussed previously. The reduction in absolute weight of breast, thigh, drumstick and wing was evident only due to high SLAA deficiency, which is obvious since the requirement of valine is less (76-77\% of lysine) for optimum yield of these parameters as compared to the requirement for optimum growth ( $78 \%$ of lysine) as reported by [28]. The carcass, breast and thigh yields were decreased due to high SLAA deficiency and in contrary the drumstick and wing yield remained non-significant which sounds due to relatively less requirement of valine $(72-74 \%$ of lysine; 28$)$ and probably isoleucine and tryptophan as compared to the requirement for optimum growth. The deficiencies of isoleucine, glycine and glutamic acid [24] and of isoleucine, tryptophan and arginine [20] revealed to significantly alter carcass parameters. In one study [19] the breast meat yield was shown to be more responsive to isoleucine than to valine, which substantiates lesser valine need for breast meat yield. The relative weight of abdominal fat was increased linearly to SLAA deficiency which can be related to the ME intake per kg BWG, which also increased linearly as the SLAA deficiency increased resulting in storage of excess energy in the form of abdominal fat.

The comprehensive intake of ME, lysine, methionine + cysteine and threonine which was similar across the treatments is suggestive of the theory that birds eat to meet the nutrient demands, especially energy because the proportion of lysine, methionine + cysteine and threonine to ME was constant in all the treatments. On the other hand, intake of CP and SLAA were significantly reduced linearly to SLAA deficiency which is obvious as CP and SLAA were reduced in both the treatments. According to the theory of food intake and growth proposed by Emmans [14,15], birds attempt to grow at their genetic potential, which would mean that they attempt to eat sufficient quantity of given feed (hence nutrient) required to grow at that rate. It is clear that, FI or nutrient intake is a function of BWG and hence the individual nutrient intakes were transformed per kg BWG. It was found that ME, lysine, methionine + cysteine and threonine intakes were increased linearly to the magnitude of SLAA deficiency. As the protein or AA content of a diet was reduced, pigs [29-31] and broilers [32,33] found to increase FI to meet their requirement for specific nutrient for potential growth, and the extent to which the nutrient deficiency can be compensated depends on the amount of heat that animal can lose to the environment. This perhaps pertinent to countries like in India where ambient temperature is anticipated to be more than optimal thermo neutral temperature. With this in view, it can be regarded that, excess intake of ME has refrained birds from consuming more feed and hence birds could not eat enough to compensate for the SLAA deficiency particularly in high SLAA deficit diet resulting significant growth retardation.

The RSM although was included 6-10\% of ration in previous studies [2-4], yet in all these studies, the $\mathrm{CP}$ was made homogenous by adjusting the soybean meal content of the diets. Moreover, in these studies $[34,35]$, for instance at pre-starter phase the total L-lysine level of the ration was maintained at 1.17 $1.20 \%$ and the threonine $(>0.85 \%)$ and valine $(>1.0 \%)$ levels remained excess of requirement for the given lysine levels, thus question of deficiency of third and subsequent limiting AA does not arise, which explains the reason for favorable results with inclusion of 6-10\% RSM in previous studies by balancing only for lysine and methionine. In the present study, the lysine level was maintained at $1.33 \%$ as recommended for present Cobb broilers, which subsequently increased the requirement of fourth and subsequent limiting AA resulting in a marginal deficiency in RSM based diets and high deficiency in DORB based diets. However, in previous studies, the overall FCR ranged from 1.94 to 2.13 [3] and 2.03-2.30 [4], which was obvious due to low AA density of diets and was incomparable to FCR of the present study as well as FCR of present commercial broiler industry.

The significant depression of bird performance observed in present study with DORB inclusion was in agreement with the previous findings $[7,8]$. Since, the DORB inclusion is known to reduce the essential AA content of the diet, [34] tried using limiting AA balancing for utilization of used rice bran (with oil) up to $20 \%$ of ration. However, the soybean meal content was increased to balance the limiting AA and hence, the CP was increased by $2.00 \%$ point in diet balanced for all limiting AA compared to control. In this context, the poor performance observed under $6 \%$ RSM and DORB included diets can be clearly attributed to the deficiency of SLAA.

\section{Conclusion}

The study concluded that deficiency of SLAA on RSM and DORB based diets would severely impact the bird performance, carcass parameters and abdominal fat percent depending on the extent of SLAA deficiency. Further studies needed with supplementation of L-valine, L-isoleucine and L-tryptophan to reduce protein in broiler diets by incorporation of RSM and DORB.

\section{Authors' Contributions}

CBK conceptualized the idea, carried out the experiment, analyzed the data and drafted first manuscript. RGG, KCS, TMP, S and BNS designed and guided during the experiment, helped in analysis of data, given critical inputs and revised the manuscript. 
GAM helped in carrying out experiment, involved in data collection, laboratory analysis. All authors read and approved the final version of the manuscript.

\section{Acknowledgements}

The authors duly acknowledge the support given by Veterinary College, Bangalore, India and KVAFSU for providing financial assistance for the work, which was a part of Ph.D. Research work of the first author. We also thank Dr. B.S.V. Reddy for precious technical guidance regarding commercial poultry practices. We also acknowledge the support given by Evonik Pte. Ltd. Singapore and particularly Dr. D. Kiran (Evonik Pte. Ltd. Singapore) for help in analysis of amino acid composition of the feed ingredients.

\section{Competing Interests} interests.

The authors declare that they have no competing

\section{References}

1. Carzo, A., Loar II, R.E. and Kidd, M.T. (2009) Limitations of dietary isoleucine and valine in broiler chick diets. Poult. Sci., 88(9): 1934-1938.

2. Kinal, S., Fritz, Z., Jarosz, L. and Schleicher, A. (1990) Rape seeds, partly defatted seeds and rapeseed oil meal from var. Jantar in the feeding of broilers. Rocz. Naukowe. Zootech. Monogr. Rozpr., 28: 251-260.

3. Tangtaweewipat, S., Cheva-Isarakul, B. and Sangsrijun, P. (2004) The use of mustard meal as a protein source in broiler diets. Songklanakarin J. Sci. Technol., 26(1): 23-30.

4. Thanaseelaan, V., Viswanathan, K., Venukopalan, K., Prabakaran, R. and Chellapandian, M. (2008) Effect of feeding rapeseed meal in meat type chicken. Tamil Nadu J. Vet. Anim. Sci., 4(4): 157-161.

5. Purushothaman, M.R., Agarwal, D.K. and Sadagopan, V.R. (1990) Feeding value of deoiled rice bran for broilers. Indian J. Anim. Nutr., 7(1): 59-62.

6. Khan, M.Y., Pasha, T.N., Khalique, A., Ali, Z. and Rehman, H. (2002) Effect of feeding hydrogen peroxide treated defatted rice polishing on performance of broiler chicks. Int. J. Poult. Sci., 1(6): 193-196.

7. Bhoyar, P.M., Kaduskar, M.R., Thatte, V.R., Khire, D.W. and Gawali, A.P. (1992) Performance of broilers on non-cereal ration replaced for conventional ration. Indian J. Poult. Sci., 27(4): 234-237.

8. Das, A. and Ghosh, S.K. (2000) Effect of feeding different levels of rice bran on performance of broilers. Indian J. Anim. Nutr., 17(4): 333-335.

9. Szczurek, W. (2010) Practical validation of efficacy of the standardized ileal digestible amino acid values in diet formulation for broiler chickens. J. Anim. Feed Sci., 19: 590-598.

10. Hoehler D., Lemme A., Ravindran V., Bryden W.L. and Rostagno H.S. (2006) Feed formulation in broiler chickens based on standardized ileal amino acid digestibility. In: Cruz-Suarez, L.E., Ricque-Marie, D., Tapia-Salazar, M., Nieto-Lopez, M.G., Villarreal-Cavazos, D.A., PuelloCruz, A.C. and Garcia-Ortega, A., editors. Advances in Poultry Nutrition VIII. Symposium Internacional de Nutrición Acuícola. UANL, Monterrey, Nuevo León (Mexico). p197-212.

11. AOAC. (2006) Official Methods of Analysis. $18^{\text {th }}$ ed. Association of Official Analytical Chemists International, Washington, DC.

12. India Raw Material Report Crop Year 2012, (2013) Evonik SEA Pte. Ltd. (6036), Singapore.
13. GraphPad Prism version 5.01 for Windows, GraphPad Software, San Diego California USA. Available from: http://www.graphpad.com. 20/09/2013.

14. Emmans, G.C. (1981) A model of the growth and feed intake of adlibitum fed animals, particularly poultry. In: Hilllyer, G.M., Wittemore, C.T. and Gunn, R.G., editors. Computers in Animal Production. British Society of Animal Production, UK. p103-110.

15. Emmans, G.C. (1989) The growth of turkeys. In: Nixey, C. and Grey, T.C. editors. Recent Advances in Turkey Science: Butterworths, UK. p135-166.

16. Wen, C., Chen, X., Chen G.Y., Wu, P., Chen, Y.P., Zhou, Y.M. and Wang, T. (2014) Methionine improves breast muscle growth and alters myogenic gene expression in broilers. J. Anim. Sci., 92(3): 1068-1073.

17. Carzo, A., Dozier, W.A. III. and Kidd, M.T. (2008) Valine Nutrient recommendations for ross $\mathrm{x}$ ross 308 broilers. Poult. Sci., 87(2): 335-338.

18. Berres, J., Vieira, S.L., Favero, A., Freitas, D.M., Pena, J.E.M. and Nogueira E.T. (2011) Digestible valine requirements in high protein diets for broilers from twenty-one to forty-two days of age. Anim. Feed Sci. Technol., 165: 120-124.

19. Carzo, A., Dozier, W.A. III, Loar, R.E. II., Kidd, M.T. and Tillman, P.B. (2010) Dietary limitation of isoleucine and valine in diets based on maize, soybean meal, and meat and bone meal for broiler chickens. Br. Poult. Sci., 51(4): 558-563.

20. Carzo, A., Dozier, W.A. III, Mejia, L., Zumwalt, C.D., Kidd, M.T. and Tillman, P.B. (2011) Nutritional feasibility of L-valine inclusion in commercial broiler diets. J. Appl. Poult. Res., 20: 284-290.

21. Mejia, L., Zumwalt, C.D., Kim, E.J., Tillman, P.B. and Corzo, A. (2011) Digestible isoleucine-to-lysine ratio effects in diets for broilers from 4 to 6 weeks post hatch. $J$. Appl. Poult. Res., 20: 485-490.

22. Tavernari, F.C., Lelis, G.R., Carneiro, P.R.O., Vieira, R.A., Polveiro, R.C., Luengas, J.A.P. Rostagno, H.S. and Albino, L.F.T. (2012) Effect of different digestible isoleucine/lysine ratios for broiler chickens. Rev. Bras. Zootech., 41(7): 1699-1705

23. Campos, A.M.A., Rostagno, H.S., Nogueira, E.T., Albino, L.F.T., Pereira, J.P.L. and Maia, R.C. (2012) Updating of the ideal protein for broilers: Arginine, isoleucine, valine and tryptophan. Rev. Bras. Zootech., 41(2): 326-332.

24. Berres, J., Vieira, S.L., Dozier, W.A. III, Cortes, M.E.M., De Barros, R., Nogueira, E.T. and Kutschenko, M. (2010) Broiler responses to reduced protein diets supplemented with valine, isoleucine, glycine and glutamic acid. J. Appl. Poult. Res., 19: 68-79.

25. Tavernari, F.C., Lelis, G.R., Vieira, R.A., Rostagno, H.S., Albino, L.F.T. and Oliveira Neto A.R. (2013) Valine needs in starting and growing Cobb (500) broilers. Poult. Sci., 92: 151-157.

26. Berres, J., Vieira, S.L., Kidd, M.T., Taschetto, D., Freitas, D.M., Barros, R. and Nogueira, E. T. (2010) Supplementing 1-valine and 1-isoleucine in low-protein corn and soybean meal all-vegetable diets for broilers. J. Appl. Poult. Res., 19: $373-379$.

27. Dozier, W.A. III, Tillman, P.B. and Usry, J. (2012) Interactive effects of digestible valine-and isoleucine-to-lysine ratios provided to male broilers from 4 to 6 weeks of age. J. Appl. Poult. Res., 21: 838-848.

28. Carzo, A., Kidd, M.T., Dozier, W.A. III. and Vieira, S.L. (2007) Marginality and needs of dietary valine for broilers fed all vegetable diets. J. Appl. Poult. Res., 16: 546-554.

29. Ferguson, N.S., Arnold, G.A. and Lavers, G. (2000) The response of growing pigs to amino acids as influenced by environmental temperature. 1. Threonine. Anim. Sci., 70: 287-297.

30. Ferguson, N.S., Arnold, G.A. and Lavers, G. (2000) The response of growing pigs to amino acids as influenced 
by environmental temperature. 2. Lysine. Anim. Sci., 70: 299-306.

31. Ferguson, N.S. and Gous, R.M. (2002) The response of growing pigs to amino acids as influenced by environmental temperature: Tryptophan. Anim. Sci., 74: 103-110.

32. Kemp, C., Fisher, C. and Kenny, M. (2005) Genotypenutrition interactions in broilers; response to balanced protein in two commercial strains, $15^{\text {th }}$ European Symposium on Poultry Nutrition, Balatonfüred, Hungary. p54-56.

33. Berhe, E.T. and Gous, R.M. (2005) Effect of dietary protein content on allometric relationships between carcass portions and body protein in Cobb and Ross broilers. $24^{\text {th }}$ Conference of South African Branch of WPSA, Pretoria. Jaboticabal, UNESP.

34. Piyaratne, M.K.D.K., Atapattu, N.S.B.M., Mendis, A.P.S. and Amarasinghe, A.G.C. (2009) Effects of balancing rice bran based diets foe up to four amino acids on growth performance of broilers. Trop. Agric. Res. Ext., 12(2): 57-61.

35. Thacker, P.A. and Petri, D. (2009) The effects of canola or mustard biodiesel press cake on nutrient digestibility and performance of broiler chickens. Asian Aust. J. Anim. Sci., 22(11): 1531-1539.

$* * * * * * * *$ 